University of Nebraska - Lincoln

DigitalCommons@University of Nebraska - Lincoln

Agronomy \& Horticulture -- Faculty Publications

Agronomy and Horticulture Department

2008

Nitrogen Fertilizer Rate and Weather Dictate Nutritive Value of Fall Stockpiled Bermudagrass

John A. Guretzky

University of Nebraska-Lincoln, jguretzky2@unl.edu

Jeff Ball

The Samuel Roberts Noble Foundation, Ardmore, OK

Billy J. Cook

The Samuel Roberts Noble Foundation, Ardmore, OK

Follow this and additional works at: https://digitalcommons.unl.edu/agronomyfacpub

Part of the Plant Sciences Commons

Guretzky, John A.; Ball, Jeff; and Cook, Billy J., "Nitrogen Fertilizer Rate and Weather Dictate Nutritive Value of Fall Stockpiled Bermudagrass" (2008). Agronomy \& Horticulture -- Faculty Publications. 554. https://digitalcommons.unl.edu/agronomyfacpub/554

This Article is brought to you for free and open access by the Agronomy and Horticulture Department at DigitalCommons@University of Nebraska - Lincoln. It has been accepted for inclusion in Agronomy \& Horticulture -Faculty Publications by an authorized administrator of DigitalCommons@University of Nebraska - Lincoln. 
(C) 2008 Plant Management Network.

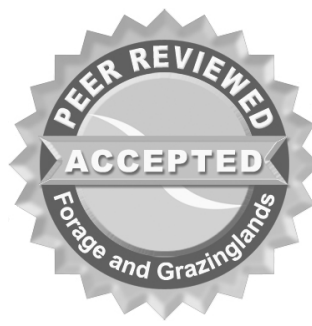

Accepted for publication 8 December 2007. Published 18 January 2008.

\title{
Nitrogen Fertilizer Rate and Weather Dictate Nutritive Value of Fall Stockpiled Bermudagrass
}

\author{
J ohn A. Guretzky, J eff Ball, and Billy J. Cook, The Samuel Roberts \\ Noble Foundation, Ardmore, OK 73401
}

Corresponding author: John A. Guretzky. jaguretzky@noble.org

Guretzky, J. A., Ball, J., and Cook, B. J. 2008. Nitrogen fertilizer rate and weather dictate nutritive value of fall stockpiled bermudagrass. Online. Forage and Grazinglands doi:10.1094/FG-2008-0118-01-RS.

\begin{abstract}
Stockpiled bermudagrass [Cynodon dactylon (L.) Pers. 'Midland'] as a standing forage may meet nutritional needs of beef cows during winter. Our objective was to evaluate accumulation and nutritive value of fall stockpiled bermudagrass in response to $\mathrm{N}$ fertilization rate, $\mathrm{N}$ application date, and harvest date. Research was conducted near Burneyville, OK from 2000 to 2003. Fertilization rates included $0,50,100$, and $150 \mathrm{lb} \mathrm{N}$ per acre applied on 15 August, 1 September, 15 September, 1 October, and 15 October. Forage accumulation was measured 10 days after the first killing frost; thereafter, crude protein (CP), acid detergent fiber (ADF), neutral detergent fiber (NDF), and total digestible nutrients (TDN) were assessed biweekly from 6 December to 20 February. An exceptionally hot and dry summer resulted in negligible forage production and unrepresentative forage quality in 2000. Forage accumulated linearly in 2001 and 2002 and quadratically in 2003 with $\mathrm{N}$ fertilization rate $(\mathrm{P} \leq 0.05)$. The dry matter averaged $56 \%$ TDN and 6.0,6.9, 7.9, and $8.7 \%$ CP when $\mathrm{N}$ was applied at $0,50,100$, and $150 \mathrm{lb} / a c r e$, respectively. The fertilized bermudagrass stands would have met $\mathrm{CP}$ and TDN requirements of mid-gestation beef cows had they been maintained on this forage.
\end{abstract}

\section{Stockpiled Bermudagrass: A Low Cost Winter Feed}

Strategies that extend the grazing season and reduce hay consumption during winter may increase profitability of beef cattle operations. In the southern United States, bermudagrass can be stockpiled and utilized as standing forage in the fall and winter. Fertilized stockpiled bermudagrass maintains adequate $\mathrm{CP}$ concentrations to meet nutritional needs of beef cows $(7,8,10)$. Costs associated with the production and feeding of stockpiled bermudagrass have been estimated to be $57 \%$ of those associated with feeding hay (4). Despite these benefits, stockpiled bermudagrass experiences significant losses in nutritional value over winter $(1,7,8)$ and may require use of supplements to maintain body weight and condition of spring-calving beef cows (10).

Accumulation and nutritive value of fall stockpiled bermudagrass have not been determined for southern Oklahoma nor has the effect of $\mathrm{N}$ application time been considered in previous studies (4). Agronomic management recommendations are frequently region and soil-specific. Our objective was to evaluate the effects of $\mathrm{N}$ fertilization rate, $\mathrm{N}$ application date, and winter harvest date on accumulation and nutritive value of fall stockpiled bermudagrass on a fine sandy loam soil in southern Oklahoma.

\section{Experimental Procedures, Design, and Analysis}

The research was conducted on a Minco fine sandy loam soil at the Noble Foundation Red River Demonstration and Research Farm near Burneyville, OK from 2000 to 2003. Burneyville, OK is located in Love Co., a county whose southern boundary is formed by the Red River separating Oklahoma and Texas. Adjacent counties to the east and west include Marshall and Jefferson counties, respectively. Fine sandy loam soils occupy 190,000 acres or $17 \%$ of the land area within these counties alone (9). 
Treatments applied to $12 \times 20$-ft plots of 'Midland' bermudagrass included $\mathrm{N}$ fertilizer rates (o, 50, 100, and $150 \mathrm{lb} /$ acre) and $\mathrm{N}$ application dates (15 August, 1 September, 15 September, 1 October, and 15 October). Before application of treatments each fall, the field plot area received a uniform application of $100 \mathrm{lb}$ $\mathrm{N}$ per acre in the spring based on a forage yield goal of 2 tons/acre (3). The field plot area was then mowed at a 3 -inch residue height and harvested for hay in June and in August. Phosphorous and $\mathrm{K}$ were applied to correct deficiencies according to soil tests each spring. Nitrogen was applied as ammonium nitrate.

Forage DM accumulation was measured once annually (27 November 2000, 7 December 2001, 6 December 2002, and 4 December 2003) through harvest of a $5 \times 20$-ft swath from the center of each plot at a 3 -inch residue height using a HEGE 212 forage plot harvester (Wintersteiger Inc., Salt Lake City, UT). The annual forage harvest occurred approximately two weeks after the first killing frost (14 November 2000, 21 November 2001, 27 November 2002, and 24 November 2003). Nutritive value during winter was assessed from forage collected during the initial mechanized harvest and from samples hand-clipped to a 3-inch residue height from the remainder of each plot at 15-day intervals. Because the date of the first killing frost differed each year, the initial harvest and subsequent sample collection dates also differed each year. Forage samples were analyzed for $\mathrm{CP}, \mathrm{NDF}$, and $\mathrm{ADF}$ using wet chemistry techniques (Ward Laboratories, Kearney, NE). Nitrogen was determined by the Kjeldahl procedure. Neutral detergent fiber and ADF were determined by refluxing with neutral and acid detergent solutions, respectively. The neutral detergent solution contained a heat-stable amylase. Total digestible nutrients were computed from the equation: $\mathrm{TDN}=102.7-(1.114 * \mathrm{ADF})$.

The experiment was a randomized complete block design with a split-plot arrangement of $\mathrm{N}$ application dates as whole plots and $\mathrm{N}$ rates as subplots. Treatments were applied to the same plots each year; harvest date effects on nutritive value were considered repeated measures. Due to annual variation in rainfall, forage accumulation, and harvest dates, data were analyzed by year. The data were subjected to a repeated measures analysis of variance using the Mixed Models procedure in SAS (SAS Institute Inc., Cary, NC). Mean separations were calculated with least square means $(\mathrm{P} \leq 0.05)$.

\section{Weather from 2000 to 2003}

The weather differed each year of the experiment. Bermudagrass grows best when mean daily temperatures are above $75^{\circ} \mathrm{F}(2)$. In all four years, temperatures were suitable from August through October for fall forage accumulation (Table 1). Average high temperatures in August and September 2000, however, were $7^{\circ}$ and $5^{\circ} \mathrm{F}$, respectively, above the 50 -year average high temperatures for the location. Precipitation was deficient during the falls of 2000 and 2003 (Fig. 1). Average annual precipitation across the last 50 years at Burneyville was 36 inches. Less than 1 inch of rain fell from July through September in 2000 compared to 8,5 , and 5 inches across this same period in 2001, 2002, and 2003, respectively. Precipitation was also 17 inches below the long-term annual average in 2003; the deficit occurred primarily from January through April and October through December. 
Table 1. Average high and low temperatures from July-December recorded in 2000-2003, relative to the 50-year average at Burneyville, Oklahoma.

\begin{tabular}{|l|l|c|c|c|c|c|c|c|}
\hline \multirow{2}{*}{ Year } & \multirow{2}{*}{ Average } & July & Aug & Sept & Oct & Nov & Dec \\
\cline { 3 - 8 } & \multicolumn{6}{|c|}{ Temperature $\left({ }^{\circ} \mathrm{F}\right)$} \\
\hline 2000 & Low & 72 & 72 & 62 & 58 & 37 & 27 \\
\cline { 2 - 9 } & High & 96 & 102 & 92 & 77 & 56 & 45 \\
\hline 2001 & Low & 75 & 72 & 61 & 49 & 46 & 33 \\
\cline { 2 - 9 } & High & 97 & 95 & 83 & 75 & 68 & 57 \\
\hline \multirow{2}{*}{2002} & Low & 70 & 71 & 63 & 51 & 36 & 32 \\
\cline { 2 - 9 } & High & 91 & 94 & 88 & 68 & 64 & 56 \\
\hline \multirow{2}{*}{2003} & Low & 71 & 71 & 60 & 51 & 45 & 32 \\
\cline { 2 - 9 } & High & 98 & 98 & 83 & 81 & 67 & 59 \\
\hline \multirow{2}{*}{50 -year } & Low & 72 & 70 & 63 & 53 & 41 & 33 \\
\cline { 2 - 9 } & High & 95 & 95 & 87 & 77 & 65 & 56 \\
\hline
\end{tabular}

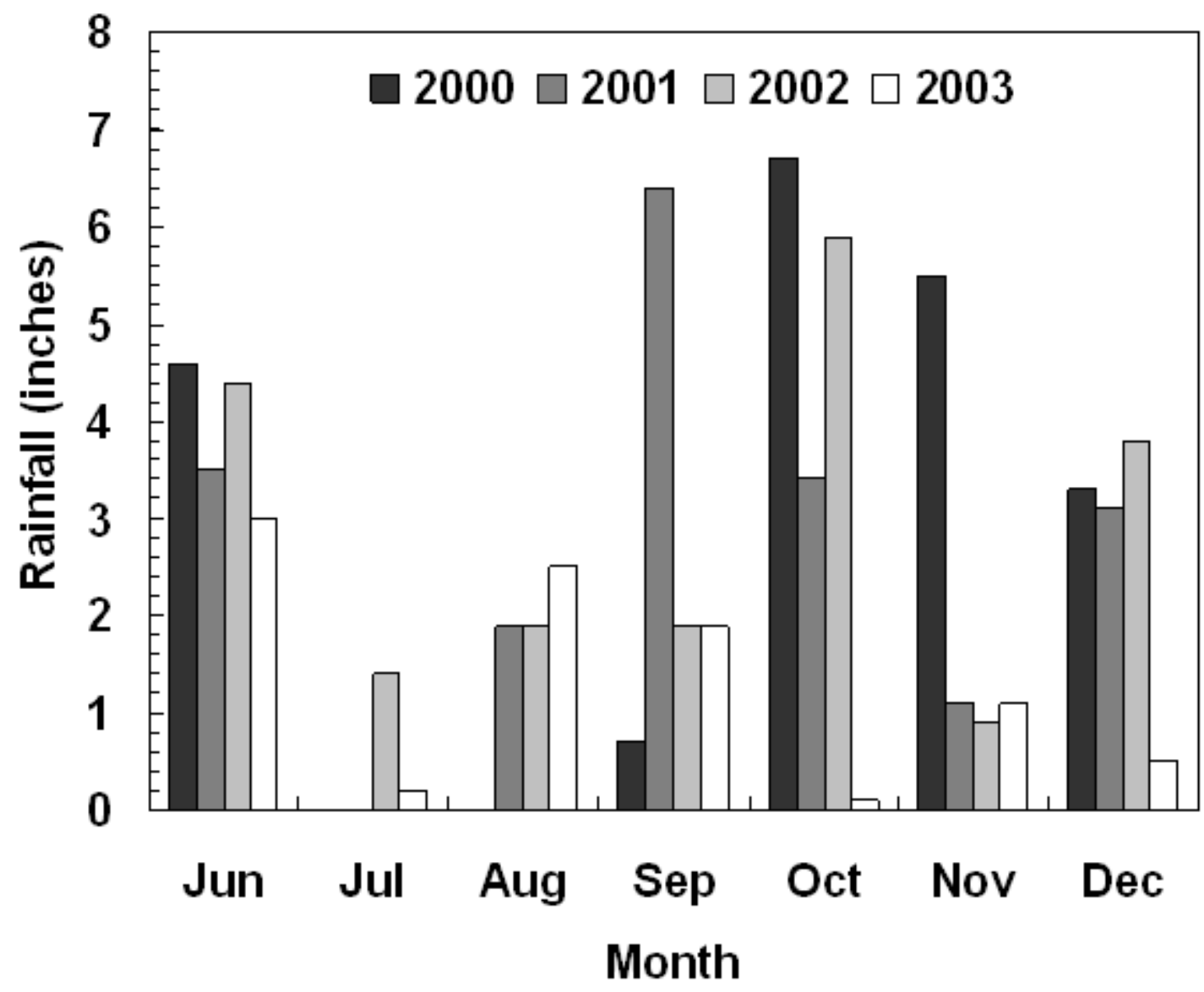

Fig. 1. June to December rainfall at Burneyville, OK, 2000 to 2003.

Nitrogen Fertilizer Rate and Application Date Effects

The exceptionally hot and dry conditions in 2000 resulted in negligible forage production and unrepresentative forage quality (data not shown).

Consequently, results from 2001 to 2003 were used to describe treatment effects on bermudagrass. In 2001, 2002, and 2003, fall forage accumulation and nutritive value was primarily affected by $\mathrm{N}$ fertilizer rate and harvest date (Table 2). Interactions were mostly nonsignificant. Nitrogen fertilizer 
rate $\times$ harvest date and $\mathrm{N}$ rate $\times$ application date interactions affected $\mathrm{CP}$ in 2001 and 2003. In 2003, the application date $\times$ harvest date interaction was also significant for CP. In 2002, only the main effects of $\mathrm{N}$ fertilizer rate and harvest date were significant.

Table 2. Probability levels by year for effects of nitrogen rate, nitrogen application date, harvest date, and their interactions on dry matter (DM) accumulation and percentages of crude protein (CP), acid detergent fiber (ADF), neutral detergent fiber (NDF), and total digestible nutrients (TDN) of stockpiled bermudagrass.

\begin{tabular}{|c|c|c|c|c|c|c|}
\hline \multirow[b]{2}{*}{ Year } & \multirow{2}{*}{$\begin{array}{l}\text { Source of } \\
\text { variation }\end{array}$} & $\begin{array}{c}\text { DM } \\
\text { accumulated }\end{array}$ & $\mathbf{C P}$ & ADF & NDF & TDN \\
\hline & & \multicolumn{5}{|c|}{$\mathbf{P}>\mathbf{F}$} \\
\hline \multirow[t]{7}{*}{2001} & Nitrogen rate $(\mathrm{N})$ & 0.022 & 0.001 & 0.004 & 0.005 & 0.004 \\
\hline & Application date (D) & 0.265 & 0.013 & 0.565 & 0.044 & 0.564 \\
\hline & $N \times D$ & 0.273 & 0.009 & 0.493 & 0.089 & 0.502 \\
\hline & \multicolumn{2}{|l|}{ Harvest date $(\mathrm{H})$} & 0.088 & 0.002 & 0.001 & 0.002 \\
\hline & \multicolumn{2}{|l|}{$\mathrm{N} \times \mathrm{H}$} & 0.004 & 0.188 & 0.111 & 0.195 \\
\hline & \multicolumn{2}{|l|}{$\mathrm{D} \times \mathrm{H}$} & 0.457 & 0.606 & 0.696 & 0.623 \\
\hline & \multicolumn{2}{|l|}{$\mathrm{N} \times \mathrm{D} \times \mathrm{H}$} & 0.080 & 0.606 & 0.526 & 0.603 \\
\hline \multirow[t]{7}{*}{2002} & Nitrogen rate $(\mathrm{N})$ & 0.136 & 0.001 & 0.030 & 0.002 & 0.031 \\
\hline & Application date (D) & 0.449 & 0.629 & 0.475 & 0.471 & 0.474 \\
\hline & $N \times D$ & 0.549 & 0.196 & 0.174 & 0.425 & 0.186 \\
\hline & \multicolumn{2}{|l|}{ Harvest date $(\mathrm{H})$} & 0.006 & 0.011 & 0.001 & 0.011 \\
\hline & \multicolumn{2}{|l|}{$\mathrm{N} \times \mathrm{H}$} & 0.256 & 0.836 & 0.160 & 0.821 \\
\hline & \multicolumn{2}{|l|}{$\mathrm{D} \times \mathrm{H}$} & 0.347 & 0.996 & 0.583 & 0.995 \\
\hline & \multicolumn{2}{|l|}{$\mathrm{N} \times \mathrm{D} \times \mathrm{H}$} & 0.876 & 0.516 & 0.257 & 0.501 \\
\hline \multirow[t]{7}{*}{2003} & Nitrogen rate $(\mathrm{N})$ & 0.007 & 0.001 & 0.080 & 0.003 & 0.085 \\
\hline & Application date (D) & 0.469 & 0.074 & 0.510 & 0.739 & 0.507 \\
\hline & $N \times D$ & 0.828 & 0.003 & 0.009 & 0.688 & 0.008 \\
\hline & \multicolumn{2}{|l|}{ Harvest date $(\mathrm{H})$} & 0.002 & 0.104 & 0.001 & 0.103 \\
\hline & \multicolumn{2}{|l|}{$\mathrm{N} \times \mathrm{H}$} & 0.001 & 0.412 & 0.571 & 0.404 \\
\hline & \multicolumn{2}{|l|}{$\mathrm{D} \times \mathrm{H}$} & 0.033 & 0.883 & 0.304 & 0.886 \\
\hline & \multicolumn{2}{|l|}{$\mathrm{N} \times \mathrm{D} \times \mathrm{H}$} & 0.297 & 0.452 & 0.536 & 0.471 \\
\hline
\end{tabular}

Forage accumulated linearly in 2001 and 2002 and quadratically in 2003 with $\mathrm{N}$ fertilization rate (Fig. 2) $(\mathrm{P} \leq 0.05)$. Across years, stockpiled bermudagrass production averaged 3450, 4000, 4170, and $4210 \mathrm{lb} /$ acre at 0,50 , 100 , and $150 \mathrm{lb} N$ per acre, respectively. Nitrogen application date did not affect fall forage accumulation (Table 2). The date when stockpiling began was likely more important to forage accumulation than $\mathrm{N}$ application date (6). In southern Oklahoma, initiation of stockpiling in early August and application of $\mathrm{N}$ fertilizer by 15 October would enable forage to accumulate before a killing frost, provided rainfall is sufficient to support growth during this period. 


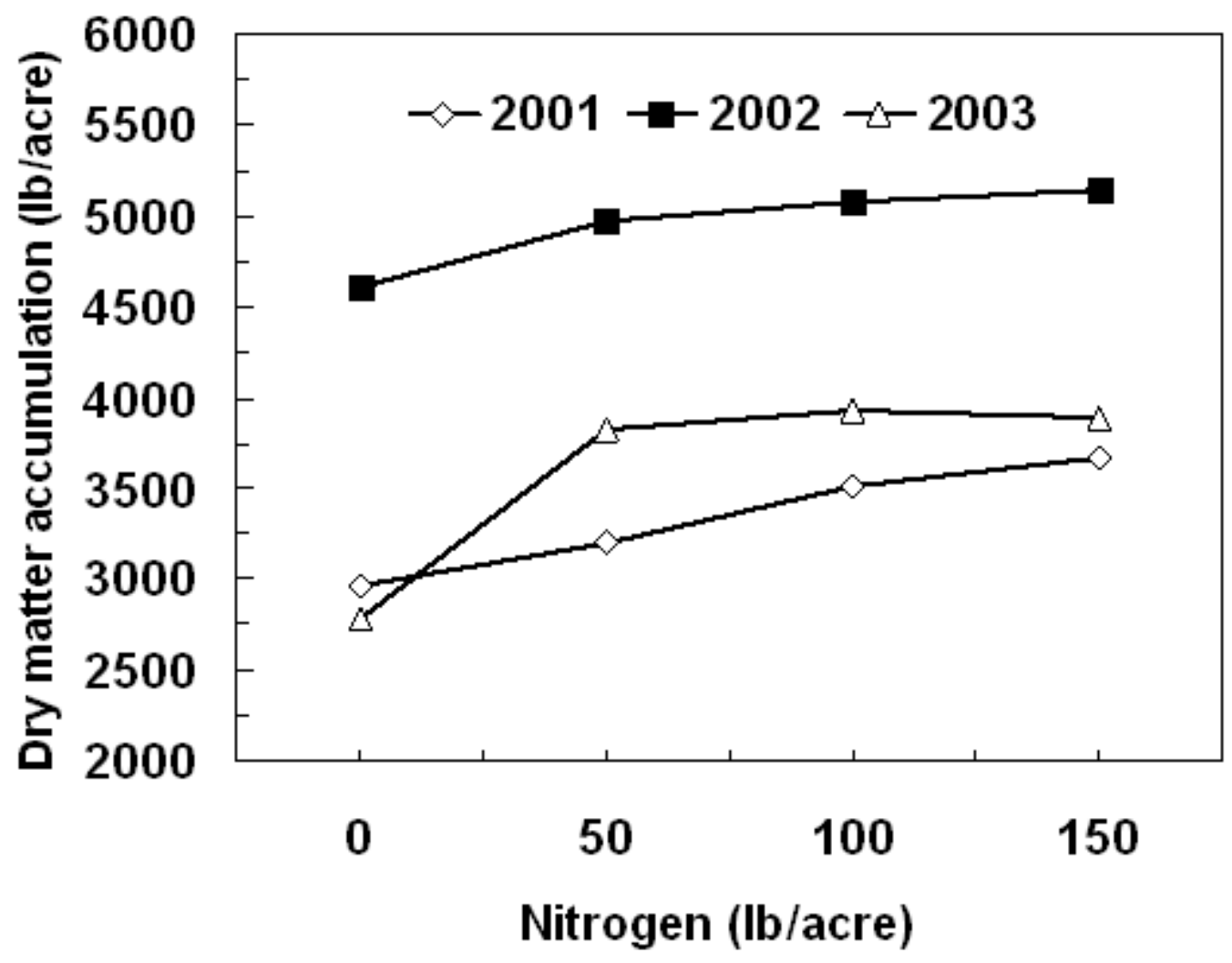

Fig. 2. Nitrogen fertilization rate effects on dry matter accumulation of stockpiled bermudagrass near Burneyville, OK on 7 December 2001, 6 December 2002, and 4 December 2003. Standard errors within each year were 190.3, 189.7, and 285.0, respectively. Values were computed across five nitrogen application dates and three replications $(n=15)$.

Forage nutritive value also increased with $\mathrm{N}$ fertilizer application (Fig. 3). Crude protein increased linearly with $\mathrm{N}$ fertilization rate each year $(\mathrm{P} \leq \mathrm{0.001})$. Although $\mathrm{N}$ fertilizer rate $\times$ application date interactions occurred in 2001 and 2003, CP was stable across application dates (data not shown). Acid detergent fiber decreased quadratically in $2001(\mathrm{P} \leq 0.05)$ and linearly in $2002(\mathrm{P} \leq 0.01)$ with $\mathrm{N}$ fertilization rate but was not affected in 2003. Responses of TDN to $\mathrm{N}$ fertilization rate were opposite that of ADF. Nitrogen fertilization rate increased TDN quadratically in $2001(\mathrm{P} \leq 0.05)$, linearly in $2002(\mathrm{P} \leq 0.01)$, but had no effect in 2003. Neutral detergent fiber decreased linearly with $\mathrm{N}$ fertilization rate in 2001 and $2002(\mathrm{P} \leq 0.001)$ and quadratically in $2003(\mathrm{P} \leq 0.05)$. 

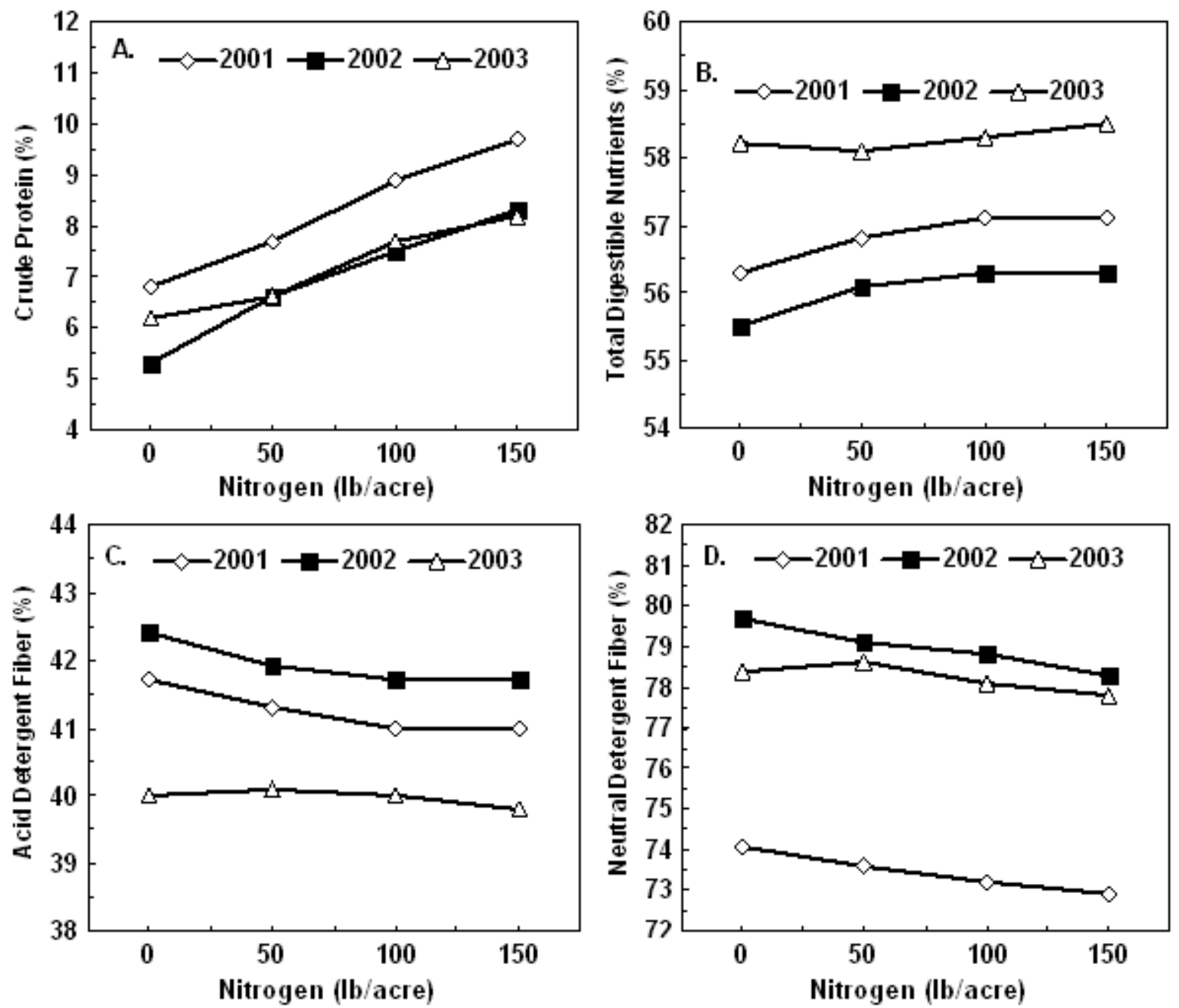

Fig. 3. Nitrogen fertilization rate effects on nutritive value of stockpiled bermudagrass near Burneyville, OK, 2001 to 2003: (A) crude protein; (B) total digestible nutrients; (C) acid detergent fiber; and (D) neutral detergent fiber. Values were computed across five nitrogen application dates, six harvest dates, and three replications $(n=90)$.

\section{Harvest Date Effects}

Nutrient concentrations often varied among harvest dates but overall exhibited small changes over the winter (Table 3). Crude protein differed as much as $0.7,2.6$, and 0.8 percentage points between successive harvest dates but changed by only $0.0,0.5$, and 1.0 percentage points from the first to the last harvest dates in 2001, 2002, and 2003, respectively. Total digestible nutrients varied as much as 1.8, 1.2, and 1.1 percentage points across successive harvest dates but declined by only $0.6,1.5$, and 0.9 percentage points from the first to last harvest dates in 2001, 2002, and 2003, respectively. Concentrations of ADF and NDF exhibited similar variability and small overall changes. Although nutritive value of fall stockpiled bermudagrass might be expected to steadily decline after a killing frost, variable weather patterns, altered leaf-to-stem ratios, growth of new tillers following periods of warm weather, and recruitment of cool-season annuals can contribute to inconsistent nutritive value responses $(7,8)$. 
Table 3. Year and harvest date effects on crude protein (CP), total digestible nutrients (TDN), acid detergent fiber (ADF), and neutral detergent fiber (NDF) of fall stockpiled bermudagrass in southern Oklahoma. Values were computed across four $\mathrm{N}$ rates, five $\mathrm{N}$ application dates, and three replications ( $\mathrm{n}=60$; $\mathrm{SEM}=$ standard error).

\begin{tabular}{|c|c|c|c|c|c|c|c|c|}
\hline \multirow{2}{*}{\begin{tabular}{|l|} 
Year \\
2001
\end{tabular}} & \multirow[b]{2}{*}{ Nutrient } & \multicolumn{6}{|c|}{ Harvest Date } & \multirow[b]{2}{*}{ SEM } \\
\hline & & 7 Dec & $4 \mathrm{~J}$ an & 17 Jan & 1 Feb & 15 Feb & 4 Mar & \\
\hline & $\mathrm{CP}$ & 8.5 & 8.4 & 7.7 & 8.3 & 8.3 & 8.5 & .26 \\
\hline & TDN & 56.7 & 57.3 & 56.4 & 56.5 & 57.9 & 56.1 & .23 \\
\hline & ADF & 41.4 & 40.8 & 41.6 & 41.5 & 40.3 & 41.9 & .21 \\
\hline & NDF & 76.6 & 74.1 & 74.4 & 72.7 & 71.5 & 71.4 & .22 \\
\hline \multirow[t]{5}{*}{2002} & Nutrient & $6 \mathrm{Dec}$ & $20 \mathrm{Dec}$ & $6 \mathrm{~J}$ an & 21 Jan & 5 Feb & 24 Feb & SEM \\
\hline & $\mathrm{CP}$ & 5.9 & 7.5 & 6.9 & 8.7 & 6.1 & 6.4 & .42 \\
\hline & TDN & 56.0 & 57.0 & 56.4 & 56.8 & 55.7 & 54.5 & .42 \\
\hline & ADF & 42.0 & 41.1 & 41.6 & 41.2 & 42.3 & 43.3 & .38 \\
\hline & NDF & 77.4 & 79.0 & 79.2 & 79.5 & 79.5 & 79.4 & .26 \\
\hline \multirow[t]{5}{*}{2003} & Nutrient & $4 \mathrm{Dec}$ & $19 \mathrm{Dec}$ & 5 Jan & $20 \mathrm{~J}$ an & 4 Feb & 20 Feb & SEM \\
\hline & $\mathrm{CP}$ & 8.1 & 7.3 & 6.7 & 6.9 & 6.8 & 7.1 & .18 \\
\hline & TDN & 58.6 & 59.6 & 58.5 & 57.9 & 57.4 & 57.7 & .77 \\
\hline & ADF & 39.7 & 38.8 & 39.7 & 40.3 & 40.8 & 40.5 & .69 \\
\hline & NDF & 74.5 & 80.4 & 79.6 & 79.3 & 78.3 & 77.2 & .32 \\
\hline
\end{tabular}

Nitrogen rate $\times$ harvest date and application date $\times$ harvest date interactions on $\mathrm{CP}$ in 2001 and 2003 resulted primarily from variability existing among harvest dates rather than variability in response to $\mathrm{N}$ fertilizer rate or $\mathrm{N}$ application date. Nutrient concentrations tended to respond positively to increased $\mathrm{N}$ fertilizer regardless of whether these effects were examined across harvest dates or by harvest date (data not shown). The lone exception was the harvest occurring on 20 January 2003 where unfertilized bermudagrass had the greatest CP.

\section{Meeting Beef Cow Nutrient Needs}

A $1200 \mathrm{lb}$, pregnant beef cow with $20 \mathrm{lb}$ of peak milk production needs a diet of $24.1 \mathrm{lb} \mathrm{DM} /$ day, $6.2 \% \mathrm{CP}$ (1.49 lb/day), and 46\% TDN (11.1 lb/day) during mid-gestation (5). These requirements increase to $24.2 \mathrm{lb} \mathrm{DM} /$ day, $7.8 \% \mathrm{CP}$ $(1.88 \mathrm{lb} /$ day), and $53 \%$ TDN (12.8 lb/day) during the last three months of pregnancy (5). The stockpiled bermudagrass would have met maintenance energy requirements during both of these periods regardless of $\mathrm{N}$ fertilization rates. On average across treatments, the bermudagrass provided 56\% TDN (13.4 $\mathrm{lb}$ TDN/day). The ability of the stockpiled bermudagrass to meet maintenance protein requirements, however, would have depended on the $\mathrm{N}$ fertilization rate and the term of pregnancy. Across years, $\mathrm{N}$ application dates, and harvest dates, the stockpiled bermudagrass averaged 6.0, 6.9, 7.9, and 8.7\% CP at o, 50, 100, and $15 \mathrm{O} \mathrm{lb} \mathrm{N}$ per acre, respectively $(1.47,1.66,1.91$, and $2.10 \mathrm{lb} \mathrm{CP} /$ day $)$. The unfertilized bermudagrass would have been deficient in CP regardless of the term of pregnancy. The fertilized bermudagrass would have met maintenance requirements for $\mathrm{CP}$ during mid-gestation regardless of $\mathrm{N}$ rate. During late gestation, however, only the bermudagrass fertilized with 100 to $150 \mathrm{lb} \mathrm{N}$ per acre would have met the $\mathrm{CP}$ requirements.

Nutrient concentrations were lower compared to other findings of fallstockpiled bermudagrass. In Arkansas, fall-stockpiled bermudagrass had concentrations of $\mathrm{CP}, \mathrm{NDF}$, and $\mathrm{ADF}$ ranging from 12 to $25 \%, 43$ to $76 \%$, and 20 to $37 \%$, respectively, depending on the location, stockpiling date, and harvest 
date (7). Concentrations of CP decreased from 14 to $13 \%$ and $\mathrm{ADF}$ increased from 31 to $40 \%$ over an October to February period in northeast Texas (1). Trials conducted at six sites across Oklahoma found CP concentrations in fallstockpiled bermudagrass generally ranged from 10 to $15 \%$ (8). One site, however, reported a range of 6 to $9 \% \mathrm{CP}$, results that agreed with our findings. Although the location of our experiment differed, the similar range of 6 to $9 \% \mathrm{CP}$ probably reflects that both trials contained 'Midland' bermudagrass on sandy loam soils.

Differences in nutrient concentrations and the degree that it changes over winter may also reflect cultivar and environment interactions. Crude protein changes over winter have been found to be positively associated with initial CP concentrations and forage maturity at first frost (1). Studies conducted in northern bermudagrass production areas also have shorter stockpiling periods than studies conducted in more southern production areas. Differences in moisture and temperature patterns may impact forage accumulation, maturity, and consequently, changes in nutritive value (4).

\section{Conclusions}

In years of favorable fall precipitation, producers can expect $4000 \mathrm{lb} / \mathrm{acre}$ of fall stockpiled bermudagrass forage with $\mathrm{N}$ applications of $5 \mathrm{o} \mathrm{lb} /$ acre on sandy loam sites in southern Oklahoma. Stockpiled bermudagrass provided on average across treatments $56 \% \mathrm{TDN}$ and 6.0, 6.9, 7.9, and 8.7\% CP when fertilized with $0,50,100$, and $150 \mathrm{lb} \mathrm{N}$ per acre, respectively. At these rates, the fertilized bermudagrass would have met maintenance requirements for energy and protein of mid-gestation beef cows. Nitrogen application date and harvest date did not dramatically affect fall forage accumulation or nutritive value.

\section{Acknowledgments}

The authors thank Julie Barrick, Amy Bridges, Tabby Campbell, Roger Hartwell, Frank Motal, and Shawn Norton for their contributions to this research.

\section{Literature Cited}

1. Evers, G. W., Redmon, L. A., and Provin, T. L. 2004. Comparison of bermudagrass, bahiagrass, and kikuyugrass as a standing hay crop. Crop Sci. 44:1370-1378.

2. Hanna, W. W., and Sollenberger, L. E. 2007. Tropical and subtropical grasses. Forages Volume II: The Science of Grassland Agriculture. R. F. Barnes, C. J. Nelson, K. J. Moore, and M. Collins, eds. Blackwell Publ., Ames, IA.

3. Johnson, G. V., Raun, W. R., Zhang, H., and Hattey, J. A. 2000. Oklahoma Soil Fertility Handbook, 5th Edn. Oklahoma Coop. Ext. Serv., Stillwater, OK.

4. Lalman, D. L., Taliaferro, C. M., Epplin, F. M., Johnson, C. R., and Wheeler, J. S. 2000. Review: Grazing stockpiled bermudagrass as an alternative to feeding harvested forage. Online. Proc. of the Am. Soc. of Anim. Sci. Symp., Lexington, KY 29 January to 2 February 2000. ASAS, Savoy, IL.

5. National Research Council. 2000. Nutrient Requirements of Beef Cattle, 7th Edn. National Academy Press, Washington DC.

6. Scarbrough, D. A., Coblentz, W. K., Coffey, K. P., Harrison, K. F., Smith, T. F., Hubbell, D. S. III, Humphry, J. B., Johnson, Z. B., and Turner, J. E. 2004. Effects of nitrogen fertilization rate, stockpiling initiation date, and harvest date on canopy height and dry matter yield of autumn-stockpiled bermudagrass. Agron. J. 96:538-546.

7. Scarbrough, D. A., Coblentz, W. K., Coffey, K. P., Hubbell, D. S. III, Smith, T. F., Humphry, J. B., Jennings, J. A., Ogden, R. K., and Turner, J. E. 2006. Effects of forage management on the nutritive value of stockpiled bermudagrass. Agron. J. 98:1280-1289.

8. Taliaferro, C. M., Coleman, S. W., and Claypool, P. L. 1987. Relative winter forage quality of selected bermudagrass cultivars. Crop Sci. 27:1285-1290.

9. USDA-NRCS. 2007. Web soil survey. Online. United States Department of Agriculture Natural Resources Conservation Service (USDA-NRCS), Washington, DC.

10. Wheeler, J. S., Lalman, D. L., Horn, G. W., Redmon, L. A., and Lents, C. A. 2002. Effects of supplementation on intake, digestion, and performance of beef cattle consuming fertilized, stockpiled bermudagrass forage. J. Anim. Sci. 80:780-789. 